\title{
The suction-assisted curettage procedure
}

\author{
Michael SG Bell MD FRCSC, Gaby Doumit BSc MD
}

MSG Bell, G Doumit. The suction-assisted curettage procedure. Can J Plast Surg 2005;13(1):51-52.

Surgical soft tissue debridement of an inflamed or necrotic wound can be a challenging, time-consuming exercise, often with disproportionate blood loss. Suction-assisted curettage is a safe, simple and effective technique for these common, frustrating problems.

\section{Curetage par aspiration}

En présence d'inflammation ou de nécrose des tissus mous, le débridement chirurgical d'une plaie peut représenter un défi à cause du temps requis et des pertes sanguines. Or, lorsque l'on est confronté à ce type de problème complexe mais courant, le curetage par aspiration se révèle une intervention sécuritaire, simple et efficace.

\section{Key Words: Curettage; Debridement; Suction}

Suction curettage as a technique for therapeutic abortions is $\checkmark$ well-established, with a rather commendable safety rate (1-3). This operation requires a particularly precise, atraumatic technique to remove the products of conception but avoid perforation of the vascular uterus. Suction-assisted curettage helps to reduce blood loss, and considerably reduces the operative time required to perform these procedures (3). Figure 1 shows a typical Berkley suction cannula.

Devitalized tissue, in the form of slough and necrosis, can, if present in a wound, delay healing and promote infection. Wound debridement is recommended to prevent colonization progressing to clinical infection (4) and promote wound healing $(4-6)$. Necrotic tissue is inelastic and may prevent wound contraction, thereby keeping the wound open (7). There are several methods of debridement (4) including surgical, autolytic, enzymatic, mechanical, osmotic, biosurgery and laser (8). Surgical debridement is the fastest and most effective way to remove debris and necrotic tissue $(9,10)$. Steed et al $(11)$ demonstrated that sharp sterile surgical debridement to a bleeding base increases the healing rate of diabetic neurotropic ulcers. However, caution is needed where blood vessels, nerves and other structures may be present, and where the devitalized tissue extends deep into a cavity wound (10).

The present article outlines the development of a new debridement technique in surgery that is particularly useful in the removal of granulation tissue, necrotic fat and foreign material from superficial injuries and burns. This is used in conjunction with an injection of a tumescent solution to further reduce blood loss, and to facilitate the mechanical curettage of the surface by tightening and stabilizing the tissues. We have used this technique extensively in the debridement of sternal wounds and compound tibia/fibula fractures, and in cleaning up granulation tissue on burns and traumatic injuries in preparation for skin grafting. This reduces the operative time significantly, both from the mechanical removal of the soft tissue to be debrided, and in obtaining good hemostasis. A Medline search from 1963 to 2004 revealed no previous report of use of curettage in wound debridement or superficial liposuction.

Using this same equipment, we have performed a number of other operative procedures. The plastic, disposable curettes lend themselves very well to superficial liposuction. This is particularly advantageous when removing excess fat from the undersurface of an abdominoplasty flap. The excess fat can be precisely resculptured beneath Scarpa's fascia, with minimal bleeding in the process. Furthermore, we have found this to be useful in resculpturing the fat in the skin roll that is often found at the lateral extension of the inframammary fold during a breast reduction. The curettage with suction helps reduce the oozing that is occasionally encountered on the surface of the fat and fascial surfaces, presumably by simple avulsion of the small vessels. It is, in fact, quite remarkable to observe that small veins will stay intact despite fairly vigorous liposuction, confirming the safety and relative atraumatic nature of this procedure.

Our most extensive application has been with the debridement of granulation tissue, especially in burns before skin grafting. Tumescent solution is injected beneath the granulation tissue with a $2 \mathrm{~mm}$ cannula. The granulation tissue is then debrided with the suction curette. This is the most effective way of removing the tissue and obtaining a clean, relatively nonbleeding base. Furthermore, minimal 


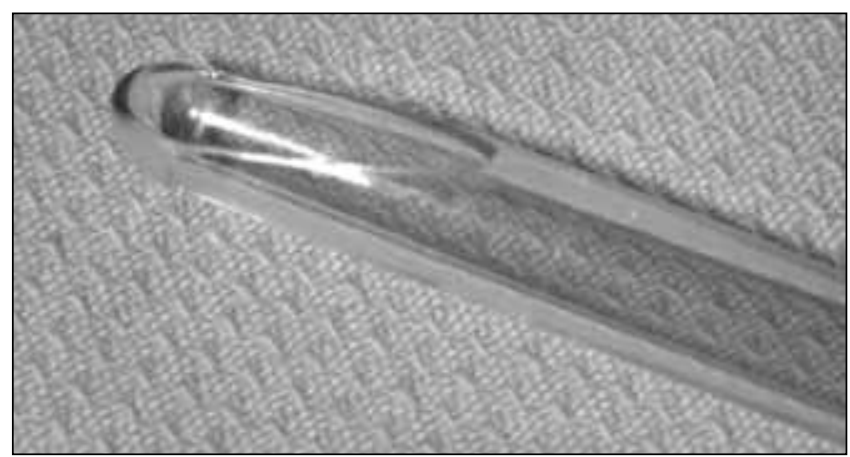

Figure 1) A typical Berkley suction cannula

cautery is required, facilitating the application and take of skin grafts.

We have used this technique to debride over 50 chronic sternal wounds. The relatively avascular fat and areas of granulation tissue along the costochondral junction and on the surface of the pericardium are quite atraumatically removed. We have used the technique similarly in pressure sores, to remove infected granulation tissue from the deepest recesses of some of these irregular ulcers. This avoids extensive mechanical excision into vascularized fibrous tissue, which may produce major blood loss and prolonged drainage at the operative site. This procedure shortens the operative time, and provides precise, controlled debridement of this tissue, which is otherwise exceedingly difficult to remove mechanically.

We have performed several debridements of compound tibia/fibula fractures with areas of necrotic fat and muscle. The curette selectively removes necrotic tissue and preserves viable tissue, again minimizing blood loss by the avulsion of the multiple small vessels that are on the surface of the wound secondary to the inflammatory process.

The mechanical control of the curette is satisfactory for our application. The small sliding ring, which can be moved over the vent in the handle, allows for the adjustment of pressure in accordance with the requirements for the wound debridement.

\section{SUMMARY}

Suction-assisted curettage has proven to be a very useful technique for surgical debridement of difficult areas. We have never had any mechanical complication from its use, even on the surface of friable inflammatory tissue with involved vessels and small superficial nerves.

\section{REFERENCES}

1. Hemlin J, Moller B. Manual vacuum aspiration, a safe and effective alternative in early pregnancy termination. Acta Obstet Gynecol Scand 2001;80:563-7.

2. Khoreva LA. [A method of vacuum aspiration in early pregnancy in women with a history of severe gynecologic diseases]. Akush Ginekol (Mosk) 1992;2:37-9.

3. Bowers CH, Chervenak JL, Chervenak FA. Late-second-trimester pregnancy termination with dilation and evacuation in critically ill women. J Reprod Med 1989;34:880-3.

4. Degreef HJ. How to heal a wound fast. Dermatol Clin 1998; 16:365-75.

5. Agren MS, Stromberg HE. Topical treatment of pressure ulcers. A randomized comparative trial of Varidase and zinc oxide. Scand J Plast Reconstr Surg 1985;19:97-100.

6. Black JM, Black SB. Surgical management of pressure ulcers. Nurs Clin North Am 1987;22:429-38.

7. Constantine BE, Bolton LL. A wound model for ischemic ulcers in the guinea pig. Arch Dermatol Res 1986;278:429-31.

8. Reynolds N, Cawrse N, Burge T, Kenealy J. Debridement of a mixed partial and full thickness burn with an erbium:YAG laser. Burns 2003;29:183-8.

9. Sibbald RG, Williamson D, Orsted HL, et al. Preparing the wound bed - debridement, bacterial balance, and moisture balance. Ostomy Wound Manage 2000;46:14-22,24-8,30-5.

10. Bale S. A guide to wound debridement. J Wound Care 1997;6:179-82.

11. Steed DL, Donohoe D, Webster MW, Lindsley L. Effect of extensive debridement and treatment on the healing of diabetic foot ulcers. Diabetic Ulcer Study Group. J Am Coll Surg 1996;183:61-4. 